\title{
Dydaktyka zdalna w czasach pandemii COVID-19 - opinie studentów, wnioski, implikacje praktyczne. Raport z badań
}

Remote teaching during the COVID-19 pandemic - students' opinions, conclusions, practical implications. Research report

\begin{abstract}
Streszczenie
Artykuł prezentuje wyniki badań własnych przeprowadzonych na próbie 507 studentów polskich uczelni, którzy z uwagi na światową sytuację pandemiczną realizowali swoje zajęcia w macierzystej uczelni w ramach kształcenia wykorzystującego metody i techniki zdalnej edukacji. Badania przeprowadzone zostały na przełomie marca i kwietnia 2021 roku, celem poznania refleksji studentów, którzy, jak można przypuszczać, oswoili się już z kształceniem realizowanym w trybie zdalnym. W związku z powyższym z badań można wyprowadzić interesujące wnioski, obrazujące zmiany w zakresie realizacji akademickiej dydaktyki zdalnej od momentu, w którym pandemia wybuchła, a władze uczelni i kadra dydaktyczna, jak również sami studenci, nie byli przygotowani do zmian sposobu uczenia się i nauczania, do stanu aktualnego, dokładnie rok po wydarzeniach inicjujących konieczność implementacji nieplanowanych zmian w procesie kształcenia. Cele badań ukierunkowane były na poznanie sposobów realizowania wykładów, zajęć praktycznych, ćwiczeniowych i laboratoryjnych w uczelniach w okresie pandemii, a nadto narzędzi komunikacji i technologii, z których
\end{abstract}

1 Anna Waligóra, Instytut Badań nad Edukacją i Komunikacją, Politechnika Śląska, Polska, e-mail: anna.waligora@polsl.pl, ORCID ID: https://orcid.org/0000-0002-5543-7010. 
nauczyciele akademiccy korzystali w procesie uczenia i konsultacji ze studentami. Badania zorientowane były na poznanie poziomu zaangażowania i motywacji studentów w proces kształcenia w czasie pandemii, jak również diagnozę czynników utrudniających studentom uczenie się w formie zdalnej. Celem badań było także poznanie kompetencji studentów, które zostały rozwinięte podczas zdalnej edukacji, a dodatkowo preferowanych przez studentów form uczenia się, umożliwiających osiąganie założonych celów dydaktycznych. Zrealizowane badania posłużyły nadto opracowaniu planu ukierunkowanego na implementację koniecznych zmian w procesie realizowania akademickiej dydaktyki zdalnej, dzięki diagnozie istotnych czynników, które w opinii badanych zostały zakwalifikowane jako wymagające udoskonalenia zarówno z perspektywy działań możliwych do wdrożenia przez uczelnię, jak i jednostkowo - przez wykładowców.

\title{
Słowa kluczowe:
}

dydaktyka zdalna, dydaktyka akademicka, kształcenie studentów podczas pandemii

\begin{abstract}
This article presents the results of own research carried out on a sample of 507 students of Polish universities who, due to the global pandemic situation, carried out their classes at their home university as part of education using remote education methods and techniques. The research was carried out at the turn of March and April 2021 to learn about the reflections of students who, as it can be assumed, have already got used to remote education. The objectives of the research were focused on learning about the methods of delivering lectures, practical, training, and laboratory classes at universities during the pandemic, as well as communication and technology tools that academic teachers used in the process of learning and communicating with students. The research was focused on identifying the level of students' involvement and motivation in the education process during a pandemic, as well as on the diagnosis of factors that make it difficult for students to learn remotely. The aim of the research was also to find out about the competencies of students, which were developed during remote education, and additionally, the forms of learning preferred by students, enabling the achievement of the assumed didactic goals.
\end{abstract}

\section{Keywords:}

remote teaching, academic didactics, students' teaching, education during the pandemic, remote learning 


\section{WPROWADZENIE}

Niniejszy artykuł stanowi komunikat z badań zrealizowanych po zakończeniu semestru zimowego w polskich uczelniach, dokładnie po upływie roku od wybuchu pandemi COVID-19. Sytuacja związana z koniecznością organizacji nauczania zdalnego była dużym wyzwaniem zarówno dla władz uczelni, dla dydaktyków akademickich, jak i dla samych studentów. Trudne sytuacje dotyczyły wielu różnorodnych sfer i wiązały się z koniecznością przemodelowania dotychczasowego sposobu realizacji zajęć w momencie zupełnie nieoczekiwanym i nieplanowanym. Uczelnie w Polsce borykały się z problemem braku dostępu do platform umożliwiających realizację edukacji zdalnej, wykładowcy doświadczali trudności z obsługą narzedzi technologii informacyjnej, deficytów sprzętowych, jak również niedostatecznie rozwiniętych własnych kompetencji praktycznych w tym zakresie. Studenci nie radzili sobie z nadmiarem zadań przeznaczonych do samodzielnej pracy, uczeniem się w warunkach odbiegających od sal akademickich czy przeznaczonych do studiowania czytelni uczelnianych bibliotek. Młodzież akademicka nierzadko nie dysponowała adekwatnym sprzętem, stabilnym łączem internetowym czy warunkami domowymi niezbędnymi do spokojnego przyswajania wiedzy (Misirli i Ergulec, 2021; Ferri, Grifoni i Guzzo, 2020; Chang i Fang, 2020; Dhawan, 2020; Verawardina i in., 2020; Yusuf, 2020; Thomas i Rogers, 2020; Alhumaid, Ali, Waheed, Zahid i Habes, 2020; Vlachopoulos, 2020). Na uwadze należy mieć również fakt, iż niespodziewany wybuch pandemii przerwał zajęcia, które realizowane były w sposób wcześniej zaplanowany, zgodnie z określonym harmonogramem i wymaganymi narzędziami dydaktycznymi, w tym wysoko specjalistycznym sprzętem laboratoryjnym, jak to ma miejsce w uczelniach technicznych czy medycznych. Zatem nie tylko warunki kształcenia uległy zmianie, ale nade wszystko metodyka nauczania poszczególnych przedmiotów. W wielu zakresach realizacja zajęć praktycznych w ogóle nie była możliwa. O tym, jak trudny był to proces, a także jak istotnie interwencyjnie uruchomiona dydaktyka zdalna odróżnia się od online learning, w swoich opracowaniach traktują tacy autorzy, jak: L. Czerniewicz (2020), D. Peixoto Olo, L. Correia i M. da Conceição Rego (2020), A. Stanger (2020), J. Zimmerman (2020), E. Johnson (2019), J. Fink (2019), P. Samson (2020), C. Hodges, S. Moore, B. Lockee, T. Trust i A. Bond (2020) i inni. Na potrzeby niniejszego artykułu i przeprowadzonych badań przyjęto następującą definicję: dydaktyka zdalna obejmuje realizację procesu dydaktycznego w warunkach, gdy nauczyciele i uczniowie (studenci) są od siebie oddaleni i nie znajdują się w tym samym miejscu, a do przekazywania informacji, oprócz tradycyjnych sposobów komunikowania się, wykorzystują także nowoczesne 
technologie telekomunikacyjne, przesyłając: głos, obraz wideo, komputerowe dane oraz materiały drukowane. Ten rodzaj nauczania może być synchroniczny, asynchroniczny lub mieszany. W procesie tym zarówno uczniowie, jak i nauczyciele współdziałają za pośrednictwem dwukierunkowych technologii komunikacyjnych. Najlepsze praktyki w zakresie zdalnego nauczania obejmują: udzielanie bieżącej informacji zwrotnej, wyjaśnianie wytycznych dotyczących zadań oraz efektywne wykorzystywanie zasobów internetowych (Kubiak, 2000; Davis, 2020; Korzan 2003; Affouneh, Salha i Khlaif, 2020; Czerniewicz i in., 2019). Jak wielkim wyzwaniem okazało się dostosowanie procesu kształcenia w oparciu o możliwości, którymi dysponowały uczelnie, do zaistniałej, kryzysowej sytuacji, pisało wielu autorów, błyskawicznie reagujących naukową refleksją na nową rzeczywistość. Wśród tekstów, które ukazują cenne refleksje i generują konteksty porównawcze, warto przytoczyć opracowania: Bozkurt i Sharma (2020), Alvarez (2020), Whalen (2020), Morgan (2020), Neuhauser (2020), Talidong (2020), Toquero (2020), ElTahir Osman (2020). Powyższe artykuły stały się także inspiracją do badań własnych, przeprowadzonych w polskich uniwersytetach i uczelniach wyższych.

\section{ZAŁOŻENIA METODOLOGICZNE}

Charakteryzowane badania zostały przeprowadzone na przełomie marca i kwietnia 2021 roku, a więc dokładnie rok od wybuchu pandemii i związanej z nią konieczności wdrożenia nauczania w formie zdalnej. Przedmiot badań stanowił proces realizacji dydaktyki zdalnej w polskich uczelniach w semestrze zimowym roku akademickiego 2020/2021. Celem przeprowadzonych badań było poznanie opinii studentów, którzy, jak można przypuszczać, oswoili się już z kształceniem realizowanym w trybie zdalnym. Badania były również ukierunkowane na wyprowadzenie wniosków, obrazujących zmiany w zakresie realizacji akademickiej dydaktyki zdalnej od momentu, w którym pandemia wybuchła, a władze uczelni i kadra dydaktyczna, jak również sami studenci nie byli przygotowani do zmian sposobu uczenia się i nauczania, do stanu aktualnego, dokładnie rok po wydarzeniach inicjujących konieczność wdrożenia nieplanowanych zmian w procesie kształcenia. Celem badań było poznanie sposobów realizowania wykładów, zajęć praktycznych, ćwiczeniowych i laboratoryjnych w polskich uczelniach w okresie pandemii, a nadto narzędzi komunikacji i technologii, z których nauczyciele akademiccy korzystali w procesie uczenia i komunikacji ze studentami. Badania zorientowane były na poznanie poziomu zaangażowania i motywacji studentów w proces kształcenia w czasie pandemii, jak również na diagnozę czynników 
utrudniających studentom uczenie się w formie zdalnej. Nadto celem badań było także poznanie kompetencji studentów, które zostały rozwinięte podczas zdalnej edukacji, a dodatkowo preferowanych przez studentów form uczenia się, umożliwiających osiąganie założonych celów dydaktycznych. Przeprowadzone badania miały charakter ilościowy, ze względu na kryterium celu były to badania teoretyczne, diagnostyczne. Z uwagi na sformułowane problemy badawcze badania miały charakter opisowo-wyjaśniający. Próbę badawczą stanowiło 507 studentów polskich uczelni, dobranych w sposób losowy, a operat losowania stanowili wszyscy studenci studiów licencjackich i magisterskich wszystkich uczelni w kraju. W badaniach uczestniczyli studenci z ponad 50 uczelni w Polsce. Badania zostały przeprowadzone w oparciu o metodologię badań społecznych, z wykorzystaniem metody sondażu diagnstycznego. W procedurze badawczej wykorzystano technikę ankiety, zrealizowaną przy pomocy narzędzia badawczego, jakim jest autorski kwesrionariusz ankiety, składający się z 31 pytań z kafeterią zamkniętą i półotwartą. Kwestionariusz zamyka metryczka, obejmująca: płeć, wiek, uczelnię, w której student studiuje, studiowany kierunek, typ, poziom i rok studiów. Próba badawcza przedstawia się następująco: 80,9\% badanych stanowiły kobiety, 19,1\% mężczyźni. Większość badanych stanowili studenci studiów pierwszego stopnia (64,9\%), I roku studiów (42,6\%). Najmniej liczną grupę reprezentowali studenci V roku studiów (8,1\%). 47,3\% badanych to studenci w grupie wiekowej 21-23 lata, $23,9 \%$ to studenci $19-20$-letni, $17,4 \%$ to badani w grupie wiekowej 24-25 lat, a 11,4\% to studenci w wieku powyżej 25 lat.

\section{REZULTATY BADAŃ I ANALIZA WYNIKÓW}

Z przeprowadzonych badań wynika, że w zimowym semestrze roku akademickiego 2020/2021 większość wykładów, z których korzystali respondenci, realizowana była poprzez umieszczanie materiałów i treści na platformie zdalnej edukacji konkretnej uczelni. W taki sposób z wykładów korzystało 74,2\% studentów. 63,7\% badanych jednocześnie uczestniczyło w wykładach realizowanych za pośrednictwem komunikatora Zoom, a 48,1\% korzystało z wykładów realizowanych na platformie Microsoft Teams. Wyniki nie sumują się do 100\%, ponieważ badani mogli udzielić więcej niż jednej odpowiedzi. Z opinii studentów wynika, iż prowadzący korzystali również z takich platform i komunikatorów jak: Discord, Skype, Big Blue Button, Webex, Clik Meeting. Niemniej 6,9\% badanych podkreśliło, że prowadzący w większości nie realizowali wykładów, wyłącznie dostarczali materiały dydaktyczne do samodzielnej pracy, bez zapewnienia studentom kontaktu syn- 
chronicznego. 76,9\% respondentów przyznało, iż większość wykładów w uczelni realizowana była synchronicznie, zgodnie z obowiązującym planem, a 18,5\% uczestniczyło w wykładach prowadzonych w sposób mieszany, w kontakcie synchronicznym i asynchronicznym. Celem było również poznanie, w jaki sposób realizowane były zajęcia ćwiczeniowe i laboratoryjne, przewidziane w programie kształcenia. W opinii $67,7 \%$ badanych studentów ćwiczenia w uczelni były realizowane poprzez umieszczanie materiałów i treści na platformie zdalnej edukacji uczelni. 61,3\% studentów korzystało z zajęć ćwiczeniowych prowadzonych za pomocą komunikatora Teams, a 46,2\% uczestniczyło w ćwiczeniach realizowanych z wykorzystaniem narzędzia, jakim jest Zoom. Zdaniem studentów wykładowcy umieszczali materiały dydaktyczne na dostępnej w uczelni platformie, a część kontaktową prowadzili z wykorzystaniem wzmiankowanych komunikatorów. Podobnie jak w odniesieniu do wykładów, nauczyciele akademiccy korzystali w mniejszym zakresie z innych narzędzi komunikacji, jak: Webex, Skype, Clik Meeting czy Google Classroom. 5,7\% badanych wyraziło opinię, iż prowadzący w większości nie realizowali ćwiczeń, wyłącznie dostarczali materiały dydaktyczne, co w odniesieniu do analiz teoretycznych pozwala wnioskować o niższej efektywności tak realizowanego procesu dydaktycznego. W opinii zdecydowanej większości respondentów (80,5\%) ćwiczenia realizowane były synchronicznie, zgodnie z obowiązującym planem. Analizując wyniki, należy zauważyć, iż jest to wyższy wskaźnik, w porównaniu z prowadzeniem w analogiczny sposób wykładów. W odniesieniu do zajęć laboratoryjnych, wymagających specjalistycznego sprzętu i wyposażenia stanowisk, 13,8\% ankietowanych przyznało, iż zajęcia nie były realizowane w ogóle, a wyłącznie 1\% studentów uczestniczyło w laboratoriach prowadzonych stacjonarnie, w budynku uczelni, z zachowaniem reżimu sanitarnego.

Interesujące jest także zagadnienie dotyczące dostępności wykładowców podczas konsultacji i dyżurów dla studentów. Z przeprowadzonych badań wynika, iż większość: 40,8\% studentów, nie orientuje się, czy wykładowcy pełnili wzmiankowane dyżury konsultacyjne, ponieważ udzielający odpowiedzi studenci nie korzystali z takiej formy kontaktu z dydaktykiem w ciągu całego semestru realizowanej zdalnie dydaktyki. 22,5\% badanych przyznało, iż w uczelni, w której studiują, prawie wszyscy wykładowcy stosowne konsultacje pełnili, pozostając do dyspozycji studenta. Omawiane konsultacje organizowane były głównie z wykorzystaniem komunikatora Teams (41,8\% udzielonych odpowiedzi), jak również komunikatora Zoom (33,3\%). W opinii 32,9\% respondentów dydaktycy prowadzili wyłącznie mailowe konsultacje, nie oferując studentom kontaktu w formie synchronicznej. Co interesujące, 2,6\% badanych przyznało, że takowe konsultacje 
w ogóle nie były studentom oferowane, a są one elementem obligatoryjnym, wpisanym w przydział czynności oraz obowiązków zawodowych dydaktyka.

Kolejnym celem badań było poznanie zaangażowania studentów w proces realizowanych w zimowym semestrze zajęć dydaktycznych. Studenci poproszeni zostali o dokonanie subiektywnej oceny, posługując się pięciostopniową skalą, z uwzględnieniem kategorii oceny zaangażowania jako: bardzo wysokie; wysokie; przeciętne; niskie; bardzo niskie. Zdecydowana większość studentów (41,6\%) oceniła swoje zaangażowanie jako przeciętne. Zaangażowanie własne jako wysokie określiło 30,6\% badanych. Bardzo wysoko oceniło swoje zaangażowanie 14,6\% badanych, a jako niskie 10,3\%. 3\% ankietowanych przyznało, iż zaangażowanie własne ocenia na poziomie bardzo niskim. Studenci zostali również poproszeni o ocenę, czy ich poziom motywacji zmienił się w porównaniu do poprzednich lat/semestrów studiów. 53,1\% badanych przyznało, że ich motywacja uległa obniżeniu podczas nauki realizowanej w trybie zdalnym. 12\% badanych dostrzegło wzrost poziomu motywacji, a 31\% nie notuje zmiany poziomu motywacji, określając ją na poziomie stabilnym. Badani zostali także poproszeni o subiektywną ocenę poziomu motywacji nauczycieli akademickich, jak również ocenę ich zaangażowania w prowadzone zajęcia w porównaniu do poprzednich lat/semestrów studiów. 37,3\% respondentów nie dostrzega zmiany poziomu motywacji wykładowców. Jednakowoż w opinii 25,8\% badanych poziom motywacji większości nauczycieli obniżył się. Co niepokojące, blisko 8\% studentów przyznało, iż ich zdaniem dydaktycy w większości nie angażowali się w prowadzone zajęcia, a wręcz lekceważyli obowiązek ich realizacji podczas pandemii. Kolejnym celem badań była diagnoza czynników podnoszących motywację studentów podczas studiowania zdalnego. Uzyskane rezultaty wskazują, iż studentów zdecydowanie motywuje realizowanie zajęć zgodnie z ustalonym harmonogramem, czyli w sposób synchroniczny (48,5\%), jak również synchroniczny kontakt z nauczycielem (41,2\%). To istotna konkluzja, zwłaszcza jeśli zwrócimy uwagę na fakt, iż nie wszystkie zajęcia wykładowe i ćwiczeniowe odbywały się podczas pandemii w formie synchronicznej. Zatem można wnioskować, że asynchroniczna forma zajęć jest dla studentów mniej motywująca, jednocześnie nie wzbudza niezbędnego zaangażowania. Dla 47,1\% badanych motywująca jest możliwość samodzielnego planowania i organizowania nauki. Synchroniczny kontakt z grupą studencką jest czynnikiem motywującym dla 34,5\% respondentów. 27,6\% przyznaje, że motywuje zwłaszcza narzucona samodyscyplina w zakresie obowiązków akademickich. Pojawiły się także opinie badanych, wskazujące na brak czynników wzmacniajacych motywację podczas nauki zdalnej. Co prawda studenci doceniają brak konieczności codziennych dojazdów na zajęcia akademickie, a co się z tym wiąże - oszczędność czasu i fi- 
nansów, niemniej zwracają uwagę na jakość prowadzonych zajęć, która nie sprzyja ich zaangażowniu. Na uwagę i przytoczenie zasługuje opinia jednej z badanych: „Z różnych względów przebywanie na uczelni, wśród grupy studenckiej, jest dla mnie sytuacją wywołującą stres. O wiele lepiej jest mi się skupić, gdy mogę po prostu słuchać, rozmawiać, ale nie przebywać wśród tych osób”. Zatem jak wynika z badań, dla osób doświadczających trudności w relacjach interpersonalnych o różnym typie możliwość korzystania z edukacji zdalnej ogranicza konieczność angażowania się w stresujące kontakty.

Problematyka badawcza dotyczyła nadto diagnozy trudności doświadczanych przez studentów podczas zajęć zdalnych. Dla 59\% studentów dominującą trudnością był problem z dostępem do Internetu i stabilnością łącza. 42,8\% zwraca uwagę na utrudnienia w postaci awarii sprzętu, mikrofonu, kamery, oprogramowania. 41,6\% studentów doświadczyło trudności związanych z multitaskingiem, rozumianym jako konieczność wykonywania wielu aktywności jednocześnie. Dla 17,2\% przeszkodą okazał się brak odpowiedniego sprzętu i oprogramowania umożliwiającego korzystanie z zajęć zdalnych. Ten argument jest niezwykle istotny, gdyż brak narzędzi niejako wyklucza studenta z możliwości dostępu do edukacji. Co interesujące, 16,8\% respondentów nie doświadczyło żadnych trudności podczas zdalnie realizowanych wykładów i ćwiczeń. Badani zwracali również uwagę na takie niedogodności, jak: wymagania stawiane przez prowadzących; silny stres; wyczerpanie; deficyt snu; krępująca konieczność włączenia kamery; brak zdobywania praktycznego doświadczenia; trudność w znalezieniu spokojnego miejsca do nauki; rozproszenie spowodowane tym, że inni domownicy również przebywają w domu; nadto brak kontaktu z grupą; zbyt krótkie przerwy rozdzielające zajęcia; monotonność zajęć; trudność w opanowaniu materiału bez zajęć praktycznych; problemy ze skupieniem się z uwagi na mnogość rozpraszających bodźców; brak motywacji. Badani podkreślali, że długie siedzenie przed komputerem sprawia, iż produktywność i umiejętność skupienia uwagi obniża się. Analizując problem doświadczanego przez badanych multitaskingu, warto przytoczyć refleksję jednego z respondentów: „Najbardziej utrudniają mi naukę pokusy, odrywające mnie od uczestniczenia w lekcji”. Studenci zwrócili także uwagę na dolegliwości somatyczne, jak: nudności od spędzania czasu przed komputerem; ból oczu; ból kręgosłupa; ból mięśni; nieprawidłowa postawa ciała. Zdaniem większości badanych zajęcia realizowane w formie zdalnej mają negatywny wpływ na zdrowie psychiczne i fizyczne.

Celem badań było również poznanie, z jakich urządzeń studiująca młodzież korzystała podczas zajęć zdalnych. Z badań wynika, iż zdecydowana większość (89,7\%) studentów podczas nauki zdalnej pracowała, korzystając z laptopów, 65,1\% 
ze smartfonów, a 11\% z komputerów stacjonarnych. Część uczelni umożliwiała studentom wypożyczenie sprzętu komputerowego. Zwraca uwagę fakt, iż znaczny odsetek studentów podczas nauki korzystał ze smartfonów, które wymuszają inną postawę ciała, zwłaszcza w odcinku szyjnym kręgosłupa, jak i akomodację gałki ocznej (do bliży). Ponadto jakość odbioru materiałów wizualnych na małym ekranie znacznie odbiega od komfortu użytkowania monitora komputera. Niespełna 1\% badanych przyznało, że podczas nauki zdalnej wykorzystywało dodatkowy monitor, co zwiększało w opinii studentów komfort uczestnictwa w zajęciach i pozytywnie wpływało na percepcję przekazywanej wiedzy.

Objęci badaniami studenci postulowali także kwestie wymagające w ich ocenie udoskonalenia w ramach realizowanej dydaktyki zdalnej. Mając na uwadze działania, które powinna podjąć uczelnia, respondenci podkreślali zwłaszcza: konieczność jednoznacznego określenie zasad realizacji nauczania zdalnego (50,1\%); poprawę jakości i funkcjonalności platformy zdalnej edukacji (49,7\%); korektę i bardziej adekwatne do potrzeb dostosowanie planu zajęć (42,6\%). Pojawiły się także sugestie zmiany systemu prowadzenia zajęć z blokowego na standardowy, podzielony na mniejsze jednostki zajęciowe; wydłużenia czasu przeznaczonego na egzaminy i przygotowanie prac zaliczeniowych. Studenci podkreślali konieczność zwiększenia kompetencji nauczycieli, sugerując potrzebę szkoleń dla wykładowców w ramach obsługi programów, a także doskonalenie ich biegłości w posługiwaniu się narzędziami TIK. Wyniki badań wskazują, że wyłącznie 1,6\% badanych nie ma zastrzeżeń do aktualnie prowadzonej dydaktyki zdalnej i nie formułuje postulowanych do wdrożenia modyfikacji. Studenci dostrzegają także szereg zmian, które w ramach realizowanej zdalnie dydaktyki powinni wdrożyć wykładowcy, a wśród propozycji pojawiły się następujące: dostosowanie ilości materiałów do jednostki zajęć (60,7\%); podniesienie kompetencji w zakresie umiejętności posługiwania się narzędziami technologii komunikacyjnej i informacyjnej (54,4\%); poprawa jakości prowadzonych zajęć (42,6\%); podniesienie jakości udostępnianych materiałów dydaktycznych (32,9\%); budowanie relacji opartej na szacunku wobec studenta (32,7\%); udoskonalenie form przeprowadzania egzaminów i zaliczeń (31,6\%); komunikatywność (28,6\%). Studenci sygnalizują nadto potrzebę otrzymania od wykładowców pomocy i wsparcia, empatycznego zrozumienia. Młodzież zauważa, że podczas zajęć zdalnych nauczyciele szybciej mówią, co uniemożliwia notowanie i powoduje trudności z koncentracją na przekazywanych treściach. Dla badanych dużym udogodnieniem jest także możliwość nagrywania wykładów, która ułatwia dostęp do wszelkich materiałów, w tym całości wykładów (nie tylko pliku z prezentacją) w dowolnie wybranym momencie. Młodzież akademicka podkreśla jednocześnie potrzebę zwiększenia liczby zadań 
wykonywanych wspólnie z osobami z grupy w celu poprawienia relacji i kontaktu między studentami. Zatem są to doskonałe wskazówki do zaimplementowania w obszarze metodyki nauczania.

Problematyka badawcza ukierunkowana była również na diagnozę potrzeb studentów w zakresie kontynuowania zajęć realizowanych w formie zdalnej. 46\% badanych przyznało, iż oczekuje jak najszybszego powrotu na zajęcia stacjonarne. Jednak 34,7\% dobrze czuje się w obecnej sytuacji, a powrót na uczelnie do standardowego trybu kształcenia nie jest dlań priorytetem. Co interesujące, 62,8\% badanych podkreśla, że wyraża zainteresowanie realizacją części zajęć w formie zdalnej w przyszłości. Są to inspirujące wyniki badań, które pozwalają na planowanie edukacji w postpandemicznej przyszłości.

Problematykę badawczą zorientowano również na poznanie zmian, które nastąpiły w procesie realizacji zdalnej dydaktyki. Zapytano zatem studentów, jakie różnice zaobserwowali w bieżącym roku akademickim w porównaniu do semestru letniego 2019/2020, gdy pandemia wybuchła. Młodzież akademicka podkreśla, że upływ czasu spowodował, iż aktualnie zajęcia są zdecydowanie lepiej zaplanowane i zorganizowane; ograniczony został chaos, jaki pojawił się na początku, a obecnie zajęcia odbywają się według planu i materiały są udostępniane na platformie w odpowiednim czasie; zdalna dydaktyka przebiega sprawniej - nauczyciele mają już zgromadzone materiały i opracowane pomysły na prowadzenie zajęć online. W opinii badanych poprawił się nieco poziom opanowania przez wykładowców technologicznej strony zdalnego nauczania. W aspekcie lepszej organizacji zajęć studenci dostrzegają, że program kształcenia został wyraźnie dostosowany do możliwości zdalnego przekazywania wiedzy. $Z$ badań wynika, iż wcześniej (w trakcie semestru, gdy pandemia wybuchła) nie wszystkie zajęcia były prowadzone, teraz natomiast odbywają się zgodnie z planem. W semestrze letnim 2019/2020, w percepcji studentów, materiał do opanowania był zbyt obszerny, teraz wydaje się adekwatny do możliwości uczących się. Wykładowcy dostosowali metody prowadzenia zajęć do toku zdalnego. Ciekawą uwagę sformułował jeden z respondentów: „polepszono organizację zajęć oraz ujednolicono ich lokalizację do platform Teams, co pozwoliło ograniczyć chaos i niepewność, która często się pojawiała, gdy studenci nie otrzymywali informacji dotyczącej lokalizacji zajęć (platform/komunikatora) lub otrzymywali ją na ostatni moment. Wykładowcy również zauważalnie przyzwyczaili się do nowych warunków, gdzie w poprzednim semestrze widoczna była ich niechęć oraz odczuwalne było podejście to tylko chwilowe, więc będę się mniej starać (lub też wcale nie będę)”. Pojawiły się jednak wskazania, że wraz z upływem czasu obniża się poziom motywacji wykładowców i studentów. Na uwagę i przytoczenie zasługuje pisemna wypowiedź jednej 
z respondentek: „Aktualnie najbardziej męczące są zajęcia za pośrednictwem Teams. W semestrze, w którym wybuchła pandemia, otrzymywaliśmy materiały na pocztę elektroniczną i dzięki temu mogliśmy sobie zagospodarować czas sami, pracować z tym materiałem, a później tworzyć prace i projekty zaliczeniowe. To było bardziej wartościowe. Odkąd mamy zajęcia przez platformę, mam dużo słabszy wzrok, bo oprócz tego, że patrzę w ekran podczas odbywających się zajęć, to później znowu patrzę w ekran podczas robienia projektów. Zajęcia na odległość są dla mnie wygodne, bo mieszkam bardzo daleko od uczelni, ale martwi mnie to, że już nigdy bez okularów nie będę widzieć tak dobrze jak wcześniej. Zdecydowanie sądzę, że to wina poprzedniego semestru. Wcześniej takie problemy nie występowały. A w semestrze letnim 2019/2020 wywiązałam się z każdej pracy w terminie i przerobiłam cały materiał - myślę, że to istotne. Być może nie wszyscy studenci tak mają, jednak ja potrafiłam się zmotywować do samodzielnej pracy i czułam się wtedy zdrowsza”.

Materiały dydaktyczne przygotowywane przez wykładowców 57,6\% studentów ocenia jako dobrej jakości, adekwatne do przedmiotu i interesujące. 33,3\% wskazuje jednak, że część materiałów wymaga aktualizacji i solidnych uzupełnień. Diagnoza czynników powodujących największą trudność podczas nauki zdalnej wykazała, że studentom dyskomfort sprawia utrzymanie koncentracji uwagi (68,4\%); brak bezpośredniego kontaktu z grupą studencką $(64,1 \%)$; obniżający się poziom motywacji i zaangażowania (60,4\%); obecność współmieszkańców (44,4\%); brak bezpośredniego kontaktu z wykładowcą (44,8\%); zbyt obszerny materiał do opanowania w porównaniu do zajęć stacjonarnych (41,8\%); konieczność samodzielnej nauki (27,2\%); brak warunków do nauki w domu (23,3\%); brak stacjonarnych konsultacji (17\%); konieczność korzystania z technologii (13,6\%). Ważną kwestią podjętą przez ankietowanych była problematyka przeciwdziałania ściąganiu podczas różnego rodzaju zaliczeń. Pojawiły się również istotnie niepokojące wskazania studentów, jak te, że podczas nauczania zdalnego „atmosfera w domu powoduje nasilenie myśli samobójczych”; „, powodu systemu blokowego, dochodzi do patologicznych sytuacji, w których zbyt duża ilość materiału jest rozłożona w zbyt krótkim czasie”. Ankietowani zwracają uwagę także na czynniki psychiczne, związane z pandemią; utrudnienia w zdobyciu materiałów do nauki, ze względu na pobyt w domu rodzinnym i tym samym brak dostępu do biblioteki.

Studenci dostrzegają jednak, że podczas nauki realizowanej w trybie zdalnym udało im się rozwinąć szereg kompetencji interpersonalnych, takich jak:

- przystosowanie się do zmiany - 46,4\%,

- samodzielność - 45,4\%,

- zarządzanie własnym czasem - 41,4\%, 
- samodyscyplina - 38,9\%,

- dobra organizacja pracy - 34,7\%,

- obsługa nowoczesnych technologii - 31\%,

- praca pod presją czasu - 30\%,

- otwartość na nowe rozwiązania - 23,7\%,

- komunikatywność - 22,7\%,

- kreatywność - 20,9\%,

- umiejętność pracy w zespole - 19,3\%,

- odporność na stres - 17,6\%,

- skupienie się na celu i na realizacji zadania - 16,2\%,

- logiczne myślenie - 16\%,

- chęć rozwoju - 16\%,

- zaangażowanie - $14 \%$,

- asertywność - 9,3\%,

- radzenie sobie z krytyką - 5,9\%.

Zdecydowana większość studentów dostrzega zalety związane z realizacją dydaktyki w formie zdalnej. Wśród najczęściej wskazywanych pojawiają się następujące:

- oszczędność czasu na dojazdy - 92,3\%,

- oszczędność środków finansowych - 72,8\%,

- dostęp do materiałów i zajęć o każdej porze i w każdym czasie - 63,3\%,

- więcej wolnego czasu - 47,5\%,

- więcej czasu na własny rozwój - 34,3\%,

- maksymalizacja czasu przeznaczonego na naukę - 32\%,

- możliwość samodzielnego uczenia się - 25,2\%,

- łatwość komunikacji z wykładowcą z wykorzystaniem różnych narzędzi komunikacji - 25,2\%,

- poczucie bezpieczeństwa - 22,7\%.

Własne kompetencje praktyczne w zakresie posługiwania się technologiami podczas zdalnego studiowania młodzież akademicka w większości (50,3\%) ocenia jako wysoko rozwinięte. Do rozwoju tych kompetencji praktycznych bez wątpienia, zdaniem badanych, przyczyniła się realizowana zdalnie dydaktyka. Natomiast kompetencje praktyczne nauczycieli akademickich w zakresie posługiwania się technologiami podczas zdalnego nauczania tylko 13,6\% badanych ocenia jako wysoko rozwinięte, $65,9 \%$ respondentów ocenia kompetencje swoich wykładowców na poziomie przeciętnym.

Badania pozwoliły na diagnozę, czy uczelnia oferowała studentom wsparcie techniczne, merytoryczne, pomoc, szkolenia w zakresie zdalnego studiowania. 
Większość młodzieży wskazała, że takiego wsparcia nie otrzymała $(44,8 \%)$, niemniej 17,8\% respondentów korzystało z proponowanych przez uczelnie form pomocy. W kwestii niedostatków i niezaspokojonych podczas zdalnej dydaktyki potrzeb studenci wymieniają brak bezpośredniego kontaktu z nauczycielami akademickimi (55,6\%), niemniej aż 33,1\% takiego dyskomfortu związanego z izolacją nie odczuwa. Zdecydowanie bardziej dotkliwy dla uczących się jest brak bezpośredniego kontaktu z grupą studencką, który doskwiera 80,1\% badanych.

Do katalogu największych wad realizowania dydaktyki akademickiej w sposób zdalny badani zaliczają:

- brak bezpośrednich kontaktów interpesonalnych z grupą („na zajęciach nie trzeba mieć włączonych kamer, przez co nie można zobaczyć niewerbalnego przekazu, a to rodzi konflikty w grupie”);

- brak bezpośredniej interakcji pomiędzy wykładowcą a grupą; brak możliwości reagowania na grupę studencką; niedostosowanie tempa pracy do możliwości studentów;

- nienaturalne interakcje podczas zajęć („na przykład, gdy wszyscy mają wyłączone kamery, prowadzącym trudno stwierdzić, czy rozumiemy materiał lub nie wiedzą, kogo wybrać do odpowiedzi, bo nie widzą naszych reakcji na zadane pytanie”);

- brak zajęć praktycznych; brak możliwości realizacji zajęć laboratoryjnych („niektóre zajęcia, szczególnie projektowe, nie mogły być realizowane tak efektywnie, jak wcześniej, co było spowodowane utrudnieniami w komunikacji z grupą”);

- brak motywacji;

- brak pomysłowości i kreatywności nauczycieli w ramach przygotowania i przeprowadzenia zajęć (zwłaszcza praktycznych); niską jakość nauki;

- jakość prowadzonych zajęć, które nie dostarczają wystarczającej ilości wiedzy i umiejętności; niską jakość materiałów dydaktycznych;

- nadmiar materiału w porównaniu z formą stacjonarną (,pozornie dużo czasu na wykonywanie pracy, a rzeczywistość jest taka, że praktycznie nie mamy przerw od nauki”); przeciążenie materiałem („,o wiele większe wymagania i o wiele więcej materiału, brak odpowiedniego dostosowania ilości materiału do możliwości i poziomu studenta”; „więcej zadań wykonywanych często poza zajęciami”; „zbyt dużo materiału w porównaniu do studiów stacjonarnych”);

- narzuconą ilość materiału przeznaczoną do opanowania samodzielnie;

- zamiast testów na zaliczenie - projekty, które pochłaniają bardzo dużo czasu; 
- problemy z łączem internetowym (,niestabilne łącze; ciągłe problemy z uczelnianą stroną”); ryzyko utraty połączenia podczas zaliczeń; problemy techniczne podczas kolokwiów lub egzaminów, które mogą zdyskwalifikować studenta w danym terminie;

- niezrozumienie materiału, niedopowiedzenia wykładowców;

- podczas egzaminów i zaliczeń - zbyt dużą liczbę pytań (często otwartych) w stosunku do możliwości czasowych. Powoduje to znacznie zwiększony poziom stresu u studentów („,chociaż celem wg wykładowców jest ograniczenie ściągania, to tak naprawdę powoduje to, że osoby, które się uczciwie nauczyły, nie mają czasu się zastanowić się nad odpowiedzią i nie są w stanie zdążyć z udzieleniem odpowiedzi na wszystkie pytania”);

- brak przerw między zajęciami;

- brak możliwości korzystania z zasobów uczelni, np. sprzętu w laboratorium;

- mnogość bodźców rozpraszających;

- brak miejsca i warunków do nauki w domu;

- brak dostępu do biblioteki;

- brak szkoleń z obsługi platformy, na której odbywają się zajęcia;

- niskie kompetencje wykładowców, którzy nie potrafią wyświetlić prezentacji, stworzyć grupy, spotkania itp.;

- niedostatecznie organizowane prace w grupach, kiedy nie można spotykać się z innymi stacjonarnie;

- brak organizacji wykładów;

- spóźnianie się prowadzących;

- odwoływanie zajęć 5 minut przed ich rozpoczęciem;

- ciągłą pracę przed komputerem; zmęczenie (spowodowane przede wszystkim długim wpatrywaniem się w ekran), brak motywacji i skupienia;

- silny stres;

- niedostateczny samorozwój („,poczucie, że stoję w miejscu i nie rozwijam się”); regres w umiejętnościach; absolutny brak poczucia nabywania jakiejkolwiek wiedzy i umiejętności związanych z kierunkiem.

Przeprowadzona procedura badawcza umożliwiła udzielenie odpowiedzi na sformułowane problemy badawcze, jak również zebranie obszernego i cennego materiału badawczego, który może posłużyć zaprojektowaniu proponowanych do zaimplementowania zmian, ukierunkowanych na udoskonalenie zdalnie realizowanej dydaktyki akademickiej, aby uczynić ją efektywniejszą i skuteczniejszą w percepcji studentów i wykładowców. 


\section{PODSUMOWANIE}

Diagnoza istotnych czynników, które w opinii badanych zostały zakwalifikowane jako wymagające udoskonalenia zarówno z perspektywy działań możliwych do wdrożenia przez uczelnię, jak i jednostkowo - przez wykładowców, posłużyła wyprowadzeniu następujących wniosków:

- Wykłady powinny być realizowane synchronicznie, zgodnie z obowiązującym planem. Taki sposób jest oczekiwany przez studentów i w ich percepcji najdogodniejszy.

- Efektywną formą kształcenia w ramach ćwiczeń i zajęć praktycznych jest jednoczesne umieszczanie materiałów dydaktycznych na dostępnej w uczelni platformie, a nastęnie realizowanie części kontaktowej synchronicznie, z wykorzystaniem wzmiankowanych komunikatorów.

- Studentów zdecydowanie motywuje realizowanie zajęć zgodnie z ustalonym harmonogramem, planem, czyli w sposób synchroniczny.

- Wskazane jest nagrywanie wykładów, umożliwiające studentowi odsłuchanie ich i zatrzymanie w chwili, gdy potrzebuje uzupełnić notatki.

- Podczas zajęć prowadzonych zdalnie należy mówić wolniej.

- Należy umożliwić studentom konsultacje z wykładowcami prowadzone w sposób synchroniczny, a o terminach i sposobach dyżurowania poinformować w sposób zwyczajowo przyjęty, okazuje się bowiem, że studenci nie posiadają w tej kwestii wystarczającej wiedzy, a co się z tym wiąże, z konsultacji merytorycznych nie korzystają. Kontakt mailowy z wykładowcą jest formą niewystarczającą, a studenci zwracają również uwagę na konieczność systematycznego odpisywania na wiadomości.

- Należy diagnozować poziom motywacji studentów do nauki i ewaluować stosowane metody dydaktyczne, aby maksymalizować zaangażowanie studenta podczas zajęć.

- W ramach autorefleksji i autoewaluacji wykładowcy akademiccy powinni diagnozować własny poziom motywacji i zaangażowania w wypełnianie obowiązków dydaktycznych. Mając na uwadze dostrzeżoną przez studentów obniżającą się motywację nauczycieli, konieczne wydaje się wdrażanie strategii przeciwdziałających wypaleniu zawodowemu.

- Należy uświadamiać studentów w kwestii higieny i ergonomii pracy podczas nauki zdalnej z uwagi na doświadczane dolegliwości somatyczne i psychiczne. 
- Wykładowcy i studenci powinni ustawicznie doskonalić własne kompetencje praktyczne w zakresie wykorzystywania w procesie nauczania i uczenia się TIK.

- W ramach metodyki zajęć należy zwrócić uwagę na zastosowanie metod aktywizujących i angażujących studentów do pracy grupowej.

- Należy wdrożyć działania ukierunkowane na profilaktykę niesamodzielnego i nieuczciwego przystępowania do egzaminów i zaliczeń.

- Mając na uwadze sygnalizowane przez studentów trudności z koncentracją uwagi, należy rozważyć zasadność stosowania blokowego układu zajęć, jak również propozycję skrócenia jednostki zajęciowej.

- Na szeroką skalę należy wdrożyć program ochrony zdrowia psychicznego studentów, w tym w ramach psychoprofilaktyki.

\section{Bibliografia}

Affouneh, S., Salha, S., Khlaif, Z. N. (2020). Designing Quality E-Learning Environments for Emergency Remote Teaching in Coronavirus Crisis. Interdiscyplinary Journal of virtual learning, 11, 2, s. 135-137.

Alhumaid, K., Ali, S., Waheed, A., Zahid, E., Habes, M. (2020). COVID-19 \& Elearning: Perceptions \& Attitudes of Teachers towards E-Learning Acceptancein The Developing Countries. Multicult. Educ., 6.

Alvarez Jr., A.V. (2020). The phenomenon of learning at a distance through emergency remote teaching amidst the pandemic crisis. Asian Journal of Distance Education.

Bozkurt, A., Sharma, R. C. (2020). Emergency remote teaching in a time of global crisis due to CoronaVirus pandemic. Asian Journal of Distance Education.

Chang, C. L., Fang, M. (2020). E-Learning and Online Instructions of Higher Education during the 2019 Novel Coronavirus Diseases (COVID-19) Epidemic. J. Phys. Conf. Ser.

Czerniewicz, L. (2020). What We Learnt from "Going Online” during University Shutdowns in South Africa, PhilOnEdTech, 3, 15.

Czerniewicz, L., Trotter, H., Haupt, G. (2019). Online teaching in response to student protests and campus shutdowns: academics' perspectives. International Journal of Educational Technology in Higher Education, 12, 1; 16 (1):43.

Davis, E. (2020). Remote teaching. Download: https://tophat.com/glossary/r/remote-teaching/, 3, 20.

Dhawan, S. (2020). Online Learning: A Panacea in the Time of COVID-19 Crisis. J. Educ. Technol. Syst. 49, s. 5-22.

ElTahir Osman, M. (2020). Global impact of COVID-19 on education systems: the emergency remote teaching at Sultan Qaboos University. Journal of Education for Teaching International research and pedagogy, 46, 4.

Ferri, F., Grifoni, P., Guzzo, T. (2020). Online Learning and Emergency Remote Teaching: Opportunities and Challenges in Emergency Situations. Societies, 10, 86. 
Fink, J. (2019). Florida Universities Cancelling Classes, Closing Campus Ahead of Potential Category 4 Hurricane Dorian. Newsweek, 29.

Hodges, C., Moore, S., Lockee, B., Trust, T., Bond, A. (2020). The difference between emergency remote teaching and online learning. Educause Review, 27, s. 1-12.

Johnson, E. (2019). As Fires Rage, More Campuses Close. InsideHigherEd, 10, 29.

Kubiak, M.J. (2000). Szkoła, Internet, Intranet. Wirtualna edukacja. Warszawa: Wyd.

MIKOM.

Korzan, D. (2003). Ewolucja kształcenia zdalnego. W: Z. P. Kruszewski, J. Półturzycki, E. A. Wesołowska (red.), Kształcenie ustawiczne - idee i doświadczenia. Płock: Wyd. Naukowe NOVUM.

Misirli, O., Ergulec, F. (2021). Emergency remote teaching during the COVID-19

pandemic: Parents experiences and perspectives, Education and Information

Technologies.

Morgan, H. (2020). Best Practices for Implementing Remote Learning during a Pandemic.

A Journal of Educational Strategies, Issues and Ideas, 93:3, s. 134-140.

Neuhauser, C. (2020). Learning Style and Effectiveness of Online and Face-to-Face In-

struction. The American Journal of Distance Education, 16 (2), s. 99-113.

Peixoto Olo, D., Correia, L., da Conceição Rego, M. (2020). The Main Challenges of Higher Education Institutions in the 21st Century: A Focus on Entrepreneurship. W:

A. Dias Daniel, A. A. C. Teixeira, M. Torres Preto (red.), Examining the Role of Entrepreneurial Universities in Regional Development. Hershey, PA: IGI Global.

Samson, P. (2020). The Coronavirus and Class Broadcasts. Educause Review, 3, 3.

Stanger, A. (2020). Make All Courses Pass/Fail Now. Chronicle of Higher Education, 3, 19. Talidong, K. J. B. (2020). Implementation of emergency remote teaching (ERT) among Philippine teachers in Xi'an, China. Asian Journal of Distance Education, 15 (1), s. 196201.

Thomas, M.S., Rogers, C. (2020). Education, the science of learning, and the Covid-19 crisis. Prospects, 49, 87-90.

Toquero, C.M. (2020). Challenges and Opportunities for Higher Education amid the COVID-19 Pandemic: The Philippine Context. Pedagogical Research, 5 (4).

Verawardina, U., Asnur, L., Lubis, A.L., Hendriyani, Y., Ramadhani, D., Dewi, I. P., Sriwahyuni, T. (2020). Reviewing Online Learning Facing the Covid-19 Outbreak. Talent Dev. Excell, 12, s. 385-392.

Vlachopoulos, D. (2020). Covid-19: Threat or opportunity for online education? High. Learn. Res. Commun., 10, s. 16-19.

Whalen, J. (2020). Should teachers be trained in emergency remote teaching? Lessons learned from the COVID-19 pandemic. Journal of Technology and Teacher Education. Yusuf, B. N. (2020). Are we Prepared Enough? A Case Study of Challenges in Online Learning in A Private Higher Learning Institution During The Covid-19 Outbreaks. Adv. Soc. Sci. Res. J., 7, s. 205-212.

Zimmerman, J. (2020). Coronavirus and the Great Online-Learning Experiment. Chronicle of Higher Education, 3, 10. 